\title{
STUDY OF PSYCHOEMOTICAL STATE WITH GENDER CHARACTERISTICS OF MEDICAL STUDENTS DURING MEDICAL PSYCHOLOGYPRACTICAL CLASSES
}

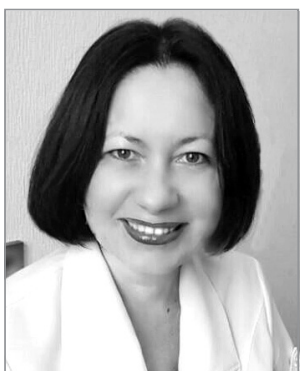

0. M. Sukachova

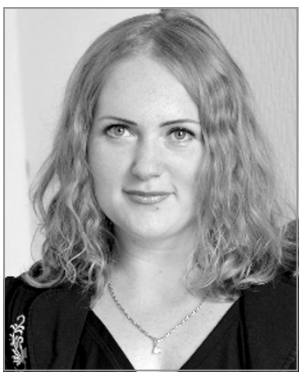

D. M. Voloshyna
(C) Olga Sukachova (Ukraine) - PhD, Assistant of the Department of Psychiatry, Narcology, Neurology and Medical Psychology, School of Medicine, V. N. Karazin Kharkiv National University, Svobody Square, 4, Kharkiv, 61000; e-mail: olga_sukachova@ukr.net; ORCID:0000-0003-0742-3041.

(с) Сукачова Ольга Миколаївна (Україна) - к.психол.н., асистент кафедри психіатрії, наркології, неврології та медичної психології, медичний факультет, Харківський національний університет імені В. Н. Каразіна, м. Харків, майдан Свободи, 4, 61000; e-mail: olga_sukachova@ukr.net; ORCID: 0000-0003-0742-3041.

(c) Сукачёва Ольга Николаевна (Украина) - к.психол.н., ассистент кафедры психиатрии, наркологии, неврологии и медицинской психологии, медицинский факультет, Харьковский национальный университет имени В. Н. Каразина, г. Харьков, площадь Свободы, 4, 61000; e-mail: olga_sukachova@ukr.net; ORCID: 0000-0003-0742-3041.

(c) Diana Voloshyna (USA) - MD, PhD, Research fellow, Substance Abuse Research Center, School of Medicine, University of Michigan; 4250 Plymouth Road, Ann Arbor, MI, USA, 48109; e-mail: voloshdin@yahoo.com; ORCID: 0000-0002-2026-9942.

(C) Волошина Діана Миколаївна (США) - К.М.Н., науковий співробітник, центр з вивчення наркології медичного факультету, Мічиганський університет; 4250 Plymouth Road, Ann Arbor, MI, USA, 48109; e-mail: voloshdin@yahoo.com; 0RCID:0000-0002-2026-9942.

(C) Волошина Диана Николаевна (США) - к.М.н., научный сотрудник, центр по изучению наркологии медицинского факультета, Мичиганский университет, г. Энн Арбор; 4250 Plymouth Road, Ann Arbor, MI, USA, 48109; e-mail: voloshdin@yahoo.com; 0RCID: 0000-0002-2026-9942.

№ 9, 2018, p. 130-134

\section{STUDY OF PSYCHOEMOTICAL STATE WITH GENDER CHARACTERISTICS OF MEDICAL STUDENTS DURING MEDICAL PSYCHOLOGYPRACTICAL CLASSES}

Abstract.

In order to study the psycho-emotional state of medical students in conducting practical classes in medical psychology, 71 third year students of the medical faculty, girls (30) and boys (41), were examined at various times. The age and gender characteristics of the psycho-emotional state of medical students were also studied. The psycho-emotional state was determined using observation, conversation, as well as using the SAN questionnaire (state of health, activity, mood). The study showed that both boys and girls had good performance on the scales of well-being and activity and high results on the mood scale, regardless of the time of the lesson. It was found that during the practical training in medical psychology, students are in a good psycho-emotional state, which has a positive effect on all cognitive processes, their volitional sphere and motor activity. At the same time, it was determined that the empathic state of the teacher is very important, as it includes the ability to respond emotionally to the students' experience; assessment and prediction and adequate behavioral response in accordance with the emotional state of students; and the possibility, if necessary, of correcting the chosen methods of joint communicative interaction. Identified gender characteristics (reduced health, activity and mood among girls during the third seminar) require further study to better understand the psychomotor processes and influence the development of proper pedagogical and psychosocial support. Studying gender characteristics and characteristics makes it possible to reform hygiene standards in the field of occupational safety and education, as well as help to improve the conduct of classes with students of the School of Medicine.

Key words: $\quad$ medical psychology, psycho-emotional state of students, gender characteristics, wellbeing, activity, mood.

ИЗУЧЕНИЕ ПСИХО-ЭМОЦИОНАЛЬНОГО СОСТОЯНИЯ С ГЕНДЕРНЫМИ ХАРАКТЕРИСТИКАМИ МЕДИЦИНСКИХ СТУДЕНТОВ В ПРОЦЕССЕ ЗАНЯТИЙ ПО МЕДИЦИНСКОЙ ПСИХОЛОГИИ

Аннотация.

\begin{abstract}
С целью изучения психоэмоционального состояния студентов-медиков при проведении практического занятия по медицинской психологии в разное время обследовали 71 студента III курса медицинского факультета - девушек (30) и юношей (41). Также были изучены поло-возрастные особенности психоэмоционального состояния студентов-медиков. Определение психоэмоционального состояния проводили при помощи наблюдения, беседы, а также с использованием опросника САН (самочувствие, активность, настроение). Исследование показало как у юношей, так и девушек хорошие показатели по шкалам самочувствия и активности и высокие результаты по шкале настроения независимо от времени проведения занятия. Было установлено, что во время прохождения практических занятий по медицинской психологии студенты находятся
\end{abstract}


в хорошем психоэмоциональном состоянии, которое оказывает положительное влияние на все когнитивные процессы, их волевую сферу и двигательную активность. В то же время, было определено, что эмпатическое состояние преподавателя очень важно, так как включает в себя способность к эмоциональному реагированию на имеющийся опыт студентов; оценку и прогнозирование и адекватное поведенческое реагирование в соответствии с эмоциональным состоянием студентов; а также возможность, в случае необходимости, исправления выбранных способов совместного коммуникативного взаимодействия. Выявленные гендерные особенности (сниженные показатели здоровья, активности и настроения среди девушек во время проведения третьего семинара) требуют дальнейшего изучения для лучшего понимания психомоторных процесов и оказания влияния на развитие правильной педагогической и психосоциальной поддержки. Изучение гендерных характеристик и особенностей дает возможность реформировать гигиенические стандарты в области безопасности труда и учебы, а также поможет улучшить проведение занятий со студентами Медицинской школы.

Ключевые слова: медицинская психология, психоэмоциональное состояние студентов, гендерные особенности, самочувствие, активность, настроение.

\section{ВИВЧЕННЯ ПСИХО-ЕМОЦІЙНОГО СТАНУ З ГЕНДЕРНИМИ ХАРАКТЕРИСТИКАМИ МЕДИЧНИХ СТУДЕНТІВ У ПРОЦЕСІ ЗАНЯТЬ 3 МЕДИЧНОї ПСИХОЛОГІ.}

Анотація.

3 метою вивчення психоемоційного стану студентів-медиків при проведенні практичного заняття з медичної психології в різний час обстежили 71 студента III курсу медичного факультету - дівчат (30) і юнаків (41). Також були вивчені статево-вікові особливості психоемоційного стану студентів-медиків. Визначення психоемоційного стану проводили за допомогою спостереження, бесіди, а також з використанням опитувальника САН (самопочуття, активність, настрій). Дослідження показало як у юнаків, так і дівчат хороші показники за шкалами самопочуття і активності і високі результати за шкалою настрою незалежно від часу проведення заняття. Було встановлено, що під час проходження практичних занять з медичної психології студенти знаходяться в хорошому психоемоційному стані, який робить позитивний вплив на всі когнітивні процеси, їх вольову сферу і рухову активність. У той же час, було визначено, що емпатичний стан викладача дуже важливий, тому що включає в себе здатність до емоційного реагування на наявний досвід студентів; оцінку і прогнозування та адекватне поведінкове реагування відповідно до емоційного стану студентів; а також можливість, у разі необхідності, виправлення обраних способів спільної комунікативної взаємодії. Виявлені гендерні особливості (знижені показники здоров'я, активності і настрою серед дівчат під час проведення третього семінару) вимагають подальшого вивчення для кращого розуміння психомоторних процесів і здійснення впливу на розвиток правильної педагогічної та психосоціальної підтримки. Вивчення гендерних характеристик і особливостей дає можливість реформувати гігієнічні стандарти в області безпеки праці і навчання, а також допоможе поліпшити проведення занять зі студентами Медичної школи.

Ключові слова: медична психологія, психоемоційний стан студентів, гендерні особливості, самопочуття, активність, настрій.

\section{Introduction}

The study of medical psychology among medical school students is a very important aspect of knowledge and skills formation applying in psychodiagnostic, psycho-prophylaxis, psychohygieneand treatment of patients, as well asdoctor-patient interaction [1]. This type of interaction needs to be paid more attention to achieving better mutual understanding between all participants in the medical process and the main task of the psychologist teacher is to instill interest and motivate students to study this discipline, since the relationship between the doctor and the patient is the basis of any medical activity [2].

In addition, the problem of the psychoemotional state, mental and physical health of students is now becoming increasingly relevant [3]. At the moment, it is important to pay attention not only to the progress of students, but also to what emotions they experience when they study at universities.
When studying the psychodynamic (personal) characteristics of students, it is necessary to take into account and unite the motivational, emotional-volitional and intellectual development of the individual into a single whole. This approach should characterize the psychological and social educationallydetermined forms of student behavior: the formation of skills, habits, restructuring of motives of behavior, features of temperament, learning abilities and sensitivity. In the student's age there is not only the accumulation of professional knowledge in the learning process, but also the active development of the personality. In the late adolescence, to which the student's age refers, the final transition to adulthood, the filling of the former qualities of the personality with a new content, the formation of social maturity, a civic position take place. Development of the personality of students occurs in communication, which has a huge subjective importance and constantly competes in duration and intensity 
with the students' learning activities and in some ways even hinders it. As this age of formation of the worldview continues, the communication of students often occurs within youth companies, associations and groupings, where young people find new friends and can show their own individuality. A very important role here is played by age, gender, physique (constitution), etc. [4]. Many of the personality traits of students should be studied not only in the context of ordinary training sessions, but also in extreme situations, e. g. during the examination session. This will provide additional information about the student.

Features of personality impose an imprint on the higher mental, and on physiological functions. Therefore, it is important to disclose those personality traits that contribute to mental adaptation, improve the performance and quality of student learning, on the one hand, and the emergence of emotional discomfort, nervous overwork and overstrain, neurotic syndrome - on the other [5].

Thus, the individual characteristics of the student's mental activity, their personal characteristics, intellectual development, temperamental qualities, emotional-volitional qualities, motivations, etc., play an important role in the success of adaptation to the conditions of study at the university, along with physiological, morphological and biochemical features of his/ her body.

Gender characteristics and features in psychomotor activity and learning processes play important role for better understanding and improving educational and hygienic standards and protocols as well as to perform prophylactic for required cohort of students. Some studies have already showed high interest in this problem and already had some gender differences founded [6-8]. But this field needs to be investigated more deeply.

\section{Purpose and objectives of the study}

Purpose of the study is to examine the psychoemotional state of medical students in conducting a practical training in medical psychology at different periods of time, and also to consider the analysis of results depending on gender.

\section{Materials and methods}

The study involved 71 third-year medical students aged 19 to 23 , girls $(n=30)$ and young men $(n=41)$.

Assessment of the psychoemotional state of students was conducted with the help of observation, conversation, and also using the SAN questionnaire (well-being, activity, mood). The authors of the SUN questionnaire (V. A. Doskin, N. A. Lavrentieva, and others) proceed from the fact that these are the main components of the functional psychoemotional state. The questionnaire consisted of 30 pairs of opposite characteristics, according to which the subjects were asked to assess their condition [9].

The significance of the differences in the results was assessed using the Student's t test.

\section{Results of research and discussion}

The study took place on the same day in different time intervals according to the schedule of classes for medical psychology. The first seminar (from 8.30 to 9.50) was attended by 20 students: girls $(n=9)$ and boys $(n=11)$. The second seminar

Results of SAN methodology among medical students (\%)

\begin{tabular}{|c|c|c|c|c|c|c|c|c|c|c|}
\hline \multirow{3}{*}{ 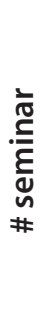 } & \multirow{3}{*}{ 这 } & \multicolumn{9}{|c|}{ Scales indicators } \\
\hline & & \multicolumn{3}{|c|}{$\begin{array}{l}\text { state } \\
\text { of health }\end{array}$} & \multicolumn{3}{|c|}{ activity } & \multicolumn{3}{|c|}{ mood } \\
\hline & & 금 & हี & 을 & 으 & $\begin{array}{l}\frac{\mathrm{E}}{3} \\
\frac{\partial}{\mathrm{d}} \\
\text { ह่ }\end{array}$ & 을 & 즈 & 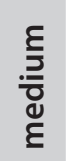 & 옹 \\
\hline \multirow{2}{*}{1} & $M$ & 18 & 9 & 73 & 9 & 55 & 36 & 9 & 0 & 91 \\
\hline & $F$ & 11 & 11 & 78 & 11 & 33 & 56 & 11 & 11 & 78 \\
\hline \multirow{2}{*}{2} & $M$ & 0 & 25 & 75 & 0 & 37 & 63 & 0 & 50 & 50 \\
\hline & $\mathbf{F}$ & 0 & 50 & 50 & 0 & 60 & 40 & 0 & 0 & 100 \\
\hline \multirow{2}{*}{3} & $M$ & 0 & 31 & 69 & 0 & 38 & 62 & 0 & 15 & 85 \\
\hline & $F$ & 14 & 43 & 43 & 0 & 71 & 29 & 29 & 14 & 57 \\
\hline \multirow{2}{*}{4} & M & 0 & 33 & 67 & 0 & 89 & 11 & 0 & 22 & 78 \\
\hline & $F$ & 0 & 50 & 50 & 25 & 25 & 50 & 0 & 50 & 50 \\
\hline
\end{tabular}

Table 2

Comparative analysis of SUN scores among medical students

\begin{tabular}{|c|c|c|c|c|c|c|c|c|}
\hline \multirow{2}{*}{ Scales } & \multicolumn{2}{|c|}{1 seminar } & \multicolumn{2}{|c|}{2 seminar } & \multicolumn{2}{|c|}{3 seminar } & \multicolumn{2}{|c|}{4 seminar } \\
\hline & $M$ & $F$ & $M$ & $F$ & $M$ & $F$ & $M$ & $F$ \\
\hline $\begin{array}{l}\text { State } \\
\text { of health }\end{array}$ & 50.1 & 3.06 & .37 & 3.07 & \pm 2.16 & 5.58 & \pm 2.83 & 48.7 \\
\hline Activity & $46.45 \pm 2.71^{*}$ & $50.00 \pm 4.07$ & $55.13 \pm 3.43^{*}$ & $49.30 \pm 2.09$ & $48.85 \pm 2.12$ & $42.14 \pm 3.96$ & $44.89 \pm 2.00^{*}$ & $46.75 \pm 9.96$ \\
\hline Mood & $56.45 \pm 3.78$ & $55.22 \pm 4.86$ & $52.88 \pm 4.51$ & $63.10 \pm 1.63^{*}$ & $53.92 \pm 2.53$ & $44.57 \pm 7.10^{*}$ & $54.89 \pm 3.35$ & $55.50 \pm 5.84$ \\
\hline
\end{tabular}

Note:

* Differences are statistically significant 


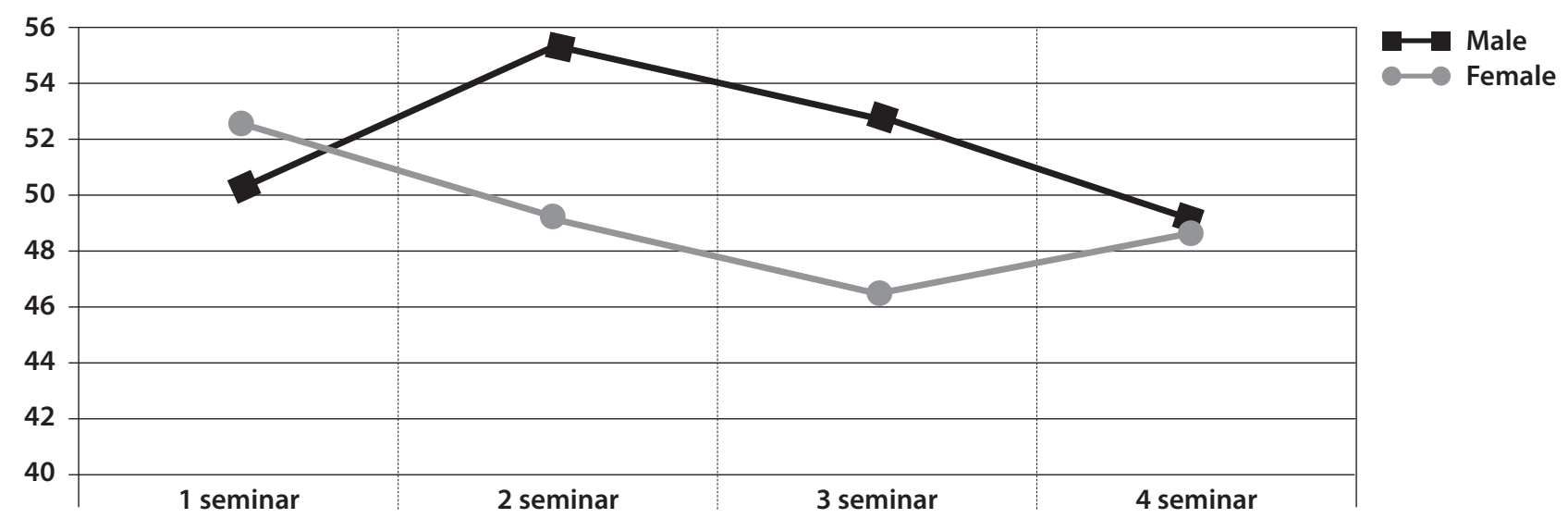

Chart 1. State of Health Scale among medical students

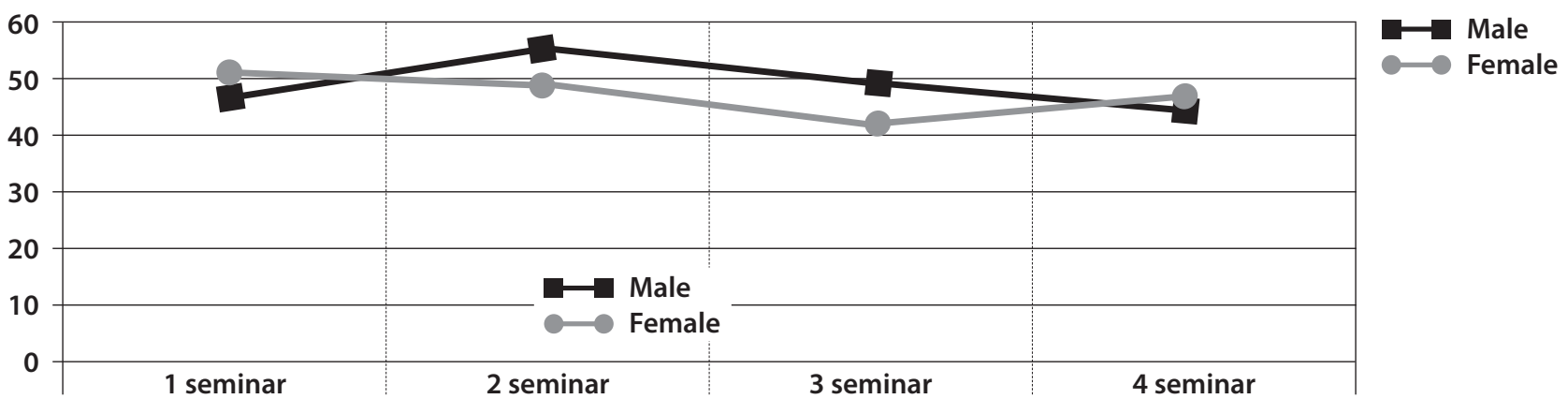

Chart 2. Activity Scale among medical students

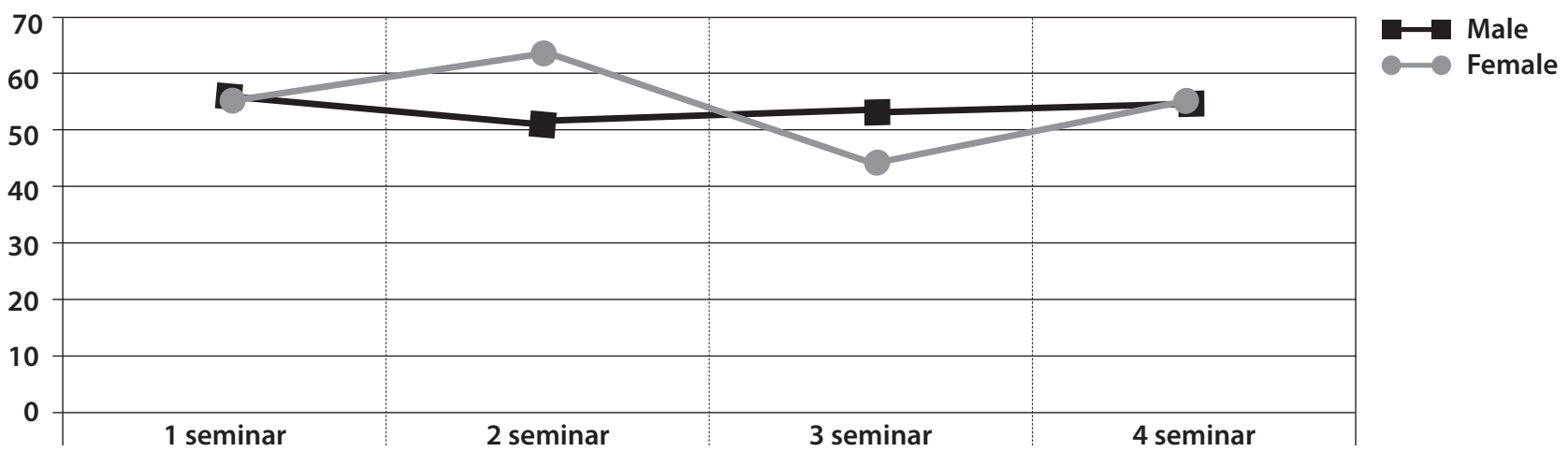

Chart 3. Mood Scale among medical students

(10.10-11.30) - 18 students: girls $(n=10)$ and boys $(n=8)$. The third seminar (from 12.00 to 13.20$)-20$ students: girls $(n=7)$ and boys $(n=13)$. And on the fourth seminar (from 13.40 to 15.00 ) - 13 students were present: girls $(n=4)$ and boys $(n=9)$.

The results of the SAN method in percentages are indicated in Table 1. After examining the indicators of well-being the scales, activity and mood, we note that the majority of students, both girls and boys, have high or medium activity, good mood and wellbeing, regardless of the time period.

Examining the results of a comparative analysis of the scores of the well-being, activity and moodscales, given in Table 2, we see that there are statistically significant differences in the activity scale among the young men between the first $(46.45 \pm 2.71)$, the second $(55.13 \pm 3.43)$ and the fourth seminars $(44.89 \pm 2.00)$.
It should be noted that the males at the second seminar had higher scores for all scales than young men at the first, third and fourth seminars. Statistically significant differences are noted in girls on a mood scale between the second $(63.10 \pm 1.63)$ and the third seminar (44.57 \pm 7.10$)$. In addition, at the first seminar among girls, the scores for all scales were higher than for the girls at other seminars and, comparatively, were identical with the results of the young men at the second seminar.

Other scores of scales from Table 2 had no statistically significant differences. Almost all students had high values on the scale of mood and good scores on the scales of well-being and activity.

This indicates that during medical psychology practice students are in a good psychoemotional state that has a positive 
effect on cognitive processes, volitional sphere and motor activity. At the same time, the teacher's empathic culture is very important, which includes the perceptive ability to respond emotionally to students' experiences; to evaluate and predict adequate ways of behavior in accordance with the emotional state of students; as well as the ability to correct selected ways of joint interaction [4].

While exploring gender characteristics of State of Health Scale among medical students, as we could see from Chart 1, very important and valuable finding should be discussed about overall health condition of females during educational process.

In contrast to males who reached their maximum health scale level at second seminar and gradually decreased to fourth seminar, females had the highest level of health at the first seminar, then gradually reached the minimum level at the third seminar, after that the level of health scale slightly was improved and became be equal to the level of health scale in males.

Features of activity process among male and female medical students are given in Chart 2. Here we could speak about the tendency similar to previously discussed but having more light differences in the scale of males and females. And again we have to emphasize the existence of minimal activity level among females at the third seminar.

Moreover and either, we could see interesting findings in gender characteristics of Mood Scale among medical students. Males showed almost the same level of mood scale during all sessions since females had the same with males' mood level at the first seminar and rising mood level during the second seminar, but dramatically falling mood level on the third seminar and again the same with males' mood level during the fourth seminar (See Chart 3).
In addition we could announce the importance of more deep investigation of decreasing state of health, activity and mood scores issues among females during the third seminar for better understanding psychomotor process and to make impact in developing right pedagogic and psychosocial support.

Studying gender characteristics and features give opportunity to reform hygienic standards in safety of work and study as well as would help to improve conducting classes with students of Medical School.

\section{Conclusion}

The study showed that in a practical lesson on medical psychology, students, both boys and girls, had good scores on the scales of wellbeing and activity, and high results on a mood scale, regardless of the time of the session. It was interesting that the guys had the highest scores at the second seminar, while the girls had the highest scores at the first seminar. It should be noted that the psychoemotional state of students, their mental and physical health, as well as their interest and activity in studying the academic discipline and interest in the chosen specialty, largely depends on the teacher's psychologicalpedagogical skillsand competence. The revealed gender specificities (reduced indicators of health, activity and mood among girls during the third seminars) require further study to better understand the psychomotor processes and influence the development of proper pedagogical and psychosocial support.

The study of gender characteristics and features makes it possible to reform hygienic standards in the field of work safety and education, and also help to improve the conduct of classes with students of the Medical School.

\section{References}

1. Лакосина Н. Д. Медицинская психология / Н. Д. Лакосина, Г. К. Ушаков.- 2-е и перераб. и доп.- М.: Медицина, 1984. - С. 272.

2. Харди И. Врач, сестра, больной. Психология работы с больными / И. Харди.- Будапешт, 1988.

3. Гуревич П. С. Актуальная психология / П. С. Гуревич // Психология и психотехника. - 2013. - № 8. - С. 742-749.

4. Березина Т. Н. Эмоциональная безопасность образовательной среды и ее влияние на субъективное состояние здоровья у студентов / Т. Н. Березина // Alma mater (Вестник высшей школы). - 2014. - № 2. - С. 36-40.

5. Саламатина Ю. В. Эмпатийная культура как профессионально-педагогическое качество учителя / Ю. В. Саламатина // Педагогическое образование в России. - 2013. - № 5. - С. 76-78.
6. Gender and age differences in psychomotor vigilance performance under differential sleep pressure conditions / K. Blatter, P. Graw, M. Munch [et al.] // Behav Brain Res. - 2006. - Vol. 168. - P. 312-317.

7. Influence of gender on psychomotor vigilance task performance by adolescents / F. Beijamini, A. G. T. Silva, C. A. T. Peixoto, F. M. Louzada // Br. J. of Medical and Biological Research. - 2008. - Vol. 41 (8). P. 734-738.

8. Males and females differ in brain activation during cognitive tasks / E. C. Bell, M. C. Willson, A. H. Wilman [et al.] // Neuroimage. - 2006. - Vol. 30. - P. 529-538.

9. Тест дифференцированной самооценки функционального состояния / В. А. Доскин, Н. А. Лаврентьева, М. П. Мирошников, В. Б. Шарай // Вопр. психологии. - 1973. - № 6. - С. 141-145. 